\title{
COMPARATIVE STUDIES OF LYMPH NODE CELL SUBPOPULATIONS AND CYTOKINE EXPRESSION IN MURINE MODEL FOR TESTING THE POTENTIALS OF CHEMICALS TO INDUCE RESPIRATORY SENSITIZATION
}

\author{
MACIEJ TARKOWSKI ${ }^{1}$, BARBARA KUR ${ }^{1}$, EWA POLAKOWSKA ${ }^{2}$, and EWA JABŁOŃSKA ${ }^{3}$ \\ ${ }^{1}$ Nofer Institute of Occupational Medicine, Łódź, Poland \\ Department of Immunotoxicology \\ ${ }^{2}$ Medical University of Łódź, Poland \\ Department of Pediatrics \\ ${ }^{3}$ Nofer Institute of Occupational Medicine, Łódź, Poland \\ Department of Toxicology and Carcinogenesis
}

\begin{abstract}
Objectives: To investigate immunological changes in lymph nodes based on expression of cell-specific receptors and cytokine expression profile and accompanying inflammatory reactions in lungs of mice treated with chemicals of known potentials to induce respiratory sensitization and those in which activity in this regard is unclear. Materials and Methods: On day 1 and 7, Balb/c mice received toluene-2,4-diisocyanate (TDI), trimellitic anhydride (TMA), 1-chloro-2,4-dinitrobenzene (DNCB), glutaraldehyde (GA), formaldehyde (FA), benzalkonium chloride (ChB) or vehicle. On day 14, they received a single intranasal instillation with the same chemical or vehicle. On day 15 , auricular lymph nodes (LN) were excised and used for analyzes of T-, B-cells, expression of CD44 and for the estimation of IL-4 and IFN- $\gamma$ production after in vitro stimulation with concanavalin A (ConA) and also for IL-4 and IFN- $\gamma$ mRNA expression analyses using Real-Time PCR. Inflammatory changes in lungs were observed by estimation of TNF- $\alpha$ and MIP-2 concentrations and cell numbers and their type in BAL. Results: There were no significant changes in cell subpopulations of T helper cells in LN. The percent of B cells was significantly increased after treatment with DNCB, TDI, and GA. Increased expression of CD44 on T cells was also observed. Both IL-4 and IFN- $\gamma$ were found increased in TDI- and FA-treated mice, while only IL-4 was increased in TMA-treated mice. Real-Time PCR analyses, however, showed increased IL-4 mRNA expression for TDI- and TMA-, and IFN- $\gamma$ mRNA expression for DNCB-treated mice. We haven't observed significant changes in inflammatory reactions in the lungs of exposed animals. Conclusions: Studying immunological changes with first determining the activation status of $\mathrm{T}$ cells followed by analyzes of expression of mRNA for Th1 and Th2 cytokines in murine model could be a useful method for assessment of the potentials of chemicals to induce respiratory sensitization but is not sufficient. Addition of ventilatory measurements, but not necessarily inflammatory reactions, could complete the model.
\end{abstract}

Key words:

Chemical-induced asthma, Dermal sensitization, Th1-Th2, Murine model, Il-4, IFN- $\gamma$

Received: October 26, 2007. Accepted: September 16, 2008.

Address reprint requests to B. Kur, Department of Immunotoxicology, Nofer Institute of Occupational Medicine, Teresy 8, 91-348 Łódź, Poland (e-mail: kur@imp.lodz.pl). 


\section{INTRODUCTION}

Workers are often exposed to chemicals with allergic potentials. Among these are high-molecular weight (HMW) compounds as well as low-molecular weight (LMW) chemicals. HMW agents, mainly consisting of proteins, induce immune response similar to common allergens. LMW chemicals in immunological terms are haptens and need to bind to host proteins to be recognized as antigen [1], but this mechanism does not seem to be true for all LMW chemicals [2].

The development of models for assessment of the potentials of LMW chemicals to induce allergic reactions is an important task for occupational health care professionals and the decisions they undertake establishing safe exposure limits. The local lymph node assay (LLNA) is now a validated method for assessing the potentials of chemicals to induce skin contact allergy [3-6]. However, until now, there is no validated method to assess the potentials of chemicals to induce respiratory sensitization.

Several groups of researchers have attempted to create a model to test chemicals' potential to induce respiratory sensitization [7-11]. In these attempts, the researchers use different animal models, including, rats, mice, and guinea pigs and assess lung ventilatory as well as immunological determinants that could predict respiratory sensitization potentials. Although their results show evident ventilatory and immunological changes characteristic of respiratory sensitization induced by known asthmogens like TDI and TMA, it is still not clear what determinant could be acceptable for assessment of chemicals with unknown sensitising potential and what change is significant. From the mechanisms of respiratory sensitization to HMW allergens it is known that major immunological factors involved are cytokines of so-called Th2 profile, including IL-4, whereas in skin sensitization the major role is played by lymphocytes $\mathrm{T}$ of Th1 profile secreting IFN- $\gamma$. The contrasting contribution of these immunological factors to respiratory or skin sensitization has been intensively utilized by researchers to identify markers enabling assessment of the potential of chemicals to induce respiratory or skin sensitization. The expression of IL-4 and IFN- $\gamma$ was assessed utilizing different techniques, including ELISA and those that measure the gene expression.

A recently established model that utilizes a modified LLNA technique [12-14] revealed apparent ventilatory changes after skin application and intranasal challenge with tested chemical. However, the underlying immunological changes were not clear. We have utilized the protocol of exposure applied by authors quoted above to test the immunological bases of the ventilatory changes with modified approach. For our analyses we have selected chemicals with known activity to induce respiratory (TDI, TMA) or skin (DNCB) sensitization. Included were also chemicals with less clear sensitization activity (GA, FA, $\mathrm{ChB}$ ). Glutaraldehyde has been recognized as a cause of occupational asthma [15] and allergic contact dermatitis [16] among healthcare workers; however, animal testing do not provide an answer confirming the ability of this chemical to induce respiratory sensitization $[17,18]$. Formaldehyde on rare occasions can induce asthma [19] and is regarded rather as an irritant [20]. Benzalkonium chloride has been found by some authors to induce allergic contact dermatitis [21], while other authors have reported its dermal as well as respiratory sensitization potentials [22]. However, in LLNA test, it is classified as irritant [23]. When establishing the animal model, it is essential to discriminate between the irritating and the immunostimulating properties of the tested chemical. Specified concentrations should evoke, or fail to evoke specific reaction, from which it is possible to conclude not only about the level of exposure but also on the character of the chemical. Such criteria are fulfilled by measurement of expression of CD44 adhesion receptor on T cells of lymph nodes draining the site of exposure [24,25]. The adhesion receptor expression is increased after antigen stimulation, while it remains unchanged when the tested substance evokes irritation. Thus, first we checked immunostimulating properties of tested chemicals by measurement of CD44 expression on T cells. Parallel to that, we determined the levels of cytokine secretion from lymph node cells draining the site of chemical application and effects in lung by measurement of inflammatory status. Based on the expression of CD44 we also selected samples to investigate expression of genes 
by Real-Time PCR. To our knowledge, several techniques have been available to test expression of genes from cells of lymph nodes in animal models [7-9,26-29], but none has utilized Real-Time PCR.

Our studies provide further information that could help establish animal model for testing the potentials of chemicals to induce skin or respiratory sensitization.

\section{MATERIALS AND METHODS}

\section{Reagents}

Toluene-2,4-diisocyanate (TDI) (Fluka, CAS 584-849, 98\%), Trimellitic anhydride (TMA) (SIGMA, CAS 552-30-7, 97\%), 1-chloro-2,4-dinitrobenzene (DNCB) (SIGMA, CAS 97-00-7, 98\%), Glutaraldehyde (GA) (SIGMA, CAS 111-30-8, 70\% solution in water), Formaldehyde (FA) (SIGMA, CAS 50-00-0, 37\% in water) and Benzalkonium chloride (ChB) (SIGMA, CAS 63449-41-2, 98\%) were obtained from Sigma (Sigma-Aldrich, Poznań, Poland). Acetone (POCH, CAS 67-64-1) was obtained from POCH (Lódź, Poland). The vehicle (AOO) used to dissolve chemicals consisted of a mixture of 2 volumes of acetone and 3 volumes of olive oil (local store). Concentrations of tested chemicals are given as percent $(\mathrm{v} / \mathrm{v}$ or $\mathrm{w} / \mathrm{v})$ in $\mathrm{AOO}$.

\section{Animals}

Male Balb/c mice, 6-8 weeks old were obtained from Nofer Institute of Occupational Medicine (tódź). The mice were housed in a conventional animal house with 12-h dark/light cycles. They received water and pelleted food ad libitum. All experimental procedures were approved by the local Ethical Committee for Animal Experiments.

\section{Treatment protocol}

All mice received dermal applications of $20 \mu$ l of vehicle or $20 \mu \mathrm{l}$ of tested chemical on each ear on days 1 and 7 . On day 14 they received, under light anesthesia using diethyl ether, an intranasal instillation of $10 \mu \mathrm{l}$ of vehicle or chemical in each nostril. Concentrations of the chemicals were based on previously published experiments testing the effects of TDI, TMA, and DNCB. The concentrations of $\mathrm{FA}, \mathrm{GA}$, and $\mathrm{ChB}$ were based on a review of published information $[5,6,25,27,28,30]$. Table I shows the concentrations of tested chemical used for each dermal contact and for intranasal challenge. On day 15, $24 \mathrm{~h}$ after intranasal challenge, mice were killed by an overdose $(100 \mathrm{mg} / \mathrm{kg}$ ip) of pentobarbital sodium (SIGMA, CAS 57-33-0) and material for ex vivo investigations was isolated in the form of bronchoalveolar lavage (BAL) and cells of lymph nodes.

\section{Bronchoalveolar lavage (BAL)}

The lungs were lavaged 3 times using $0.7 \mathrm{ml}$ of sterile solution of $0.9 \% \mathrm{NaCl}$. BAL was centrifuged at $1200 \mathrm{rpm} / \mathrm{min}$ for $10 \mathrm{~min}$. Supernatant was collected and stored at $-70^{\circ} \mathrm{C}$ for further analyses of MIP- 2 and TNF- $\alpha$ concentrations. Cell pellet was resuspended in $\mathrm{NaCl}$ and evaluated for number of cells in Neubauer hemocytometer. For differential cell count, $1 \mathrm{ml}$ of resuspended cells was span into the slides using cytocentrifuge (MPW Med Instruments, Poznań, Poland). Cells were stained according to the MayGrünwald and Giemsa protocol and 300 cells were counted for each slide.

\section{Lymph node cells}

One day after intranasal instillation, retro-auricular lymph nodes were collected from each mouse. The lymph nodes from 3 to 5 mice were pooled and kept on ice in RPMI-1640 (Gibco). Cell suspensions were obtained by pressing the lymph nodes through a cell strainer $(100 \mu \mathrm{m})$ (BD Biosciences, Poland) and rinsing with 10-ml tissue culture medium (RPMI-1640). Cells were counted using a Bürker hemocytometer. Lymphocytes were washed three times and suspended in complete tissue culture medium (RPMI-1640 supplemented with 10\% heat-inactivated fetal bovine serum, $10 \mathrm{mg} / \mathrm{ml}$ streptomycin, $100 \mathrm{IU} /$ $\mathrm{ml}$ penicillin, $1 \mathrm{mM}$ sodium pyruvate, and non-essential amino acids) at concentrations of $10^{7}$ cells $/ \mathrm{ml}$.

Five hundred thousand cells were stained with anti-CD3 (PerCP-Cy5.5 or PE), anti-CD4 (FITC), anti-CD19 (PE), and anti-CD44 (PE) labeled antibodies (BD Biosciences, Poland), according to standard procedures, while control samples were labeled with isotype match control antibodies (BD Biosciences, Poland). Flow cytometry (FacsCali- 
bur, CellQuest, BD Biosciences) was performed using at least $10^{4}$ of gated cells.

Cells were also seeded into 48-well culture plates at a density of $2 \times 10^{6} / \mathrm{ml}$ and incubated for $18 \mathrm{~h}$ without or with concanavalin A (Con A) (Sigma, Poland) $(2.5 \mu \mathrm{g} / \mathrm{ml})$. After the incubation, cells were harvested and then centrifuged, the supernatants were stored at $-80^{\circ} \mathrm{C}$ for cytokine level determinations.

\section{ELISA}

Concentrations of interleukin-4 (IL-4) and interferongamma (IFN- $\gamma$ ) were measured in undiluted supernatants of lymph node cells by standard ELISA technique, according to the manufacturer's instructions (Biosource, Polatom, Poland). Lower limits of detection were $5 \mathrm{pg} / \mathrm{ml}$ and $1 \mathrm{pg} / \mathrm{ml}$ for IL-4 and IFN- $\gamma$, respectively. The levels of MIP-2 and TNF- $\alpha$ in BAL were measured utilizing ELISA kits (Biosource, Polatom, Poland).

\section{Gene expression analyses}

For mRNA expression analyses, whole individual lymph nodes were isolated, and placed in RNAlater ${ }^{T M}$ RNA Stabilization Reagent (Qiagen, Syngen, Poland) and kept at $-80^{\circ} \mathrm{C}$ till the time of RNA isolation. For each tested chemical, 3 lymph nodes were isolated, 1 from each mouse. Total RNA was isolated by RNeasy Lipid Tissue Kit (Qiagen, Syngen, Poland) according to the manufacturer's instruction.

The cDNA was obtained by reverse transcription of $2 \mu \mathrm{g}$ of each isolated total RNA and accompanied each time by synthesis of cDNA from $2 \mu \mathrm{g}$ of mouse universal reference total RNA (SuperArray's XpressRef ${ }^{\mathrm{TM}}$ ) using a commercial kit according to the instructions of the manufacturer (ReactionReady ${ }^{\mathrm{TM}}$ First Stand cDNA Synthesis Kit, SuperArray, Prospecta, Poland).

To evaluate the levels of mRNA expression for IL-4 and IFN- $\gamma$, we used the Real Time Polymerase Chain Reaction (Real-Time PCR) technique. We have used the set of reagents commercially available (SuperArray Bioscience, Prospecta, Poland). A three-step PCR cycling program on iQ5 BioRad Cycler was used. First, samples were heated at $95^{\circ} \mathrm{C}$ for $15 \mathrm{~min}$ (activation of HotStart DNA polymerase), followed by 45 cycles at the following conditions: $95^{\circ} \mathrm{C}, 15 \mathrm{sec} ; 55^{\circ} \mathrm{C}, 30 \mathrm{sec} ; 72^{\circ} \mathrm{C}, 30 \mathrm{sec}$. Real-Time PCR was run in duplicates for each of the synthesized cDNAs. Together with Real-Time PCR for tested cDNAs, a standard curve for each gene of interest was run using cDNA synthesized from SuperArray's XpressRef ${ }^{\mathrm{TM}}$ Mouse Universal Reference Total RNA. Specificity of the reaction was checked by melting curve analyses.

\section{Data analysis}

Data are presented as mean \pm SD. Statistical analyses were performed by using non-parametric Mann-Whitney test and one-way ANOVA Bonferroni post test (GraphPad Prism 4.01).

For mRNA expression analyses (relative expression of the genes) we used software supplied by BioRad. The estimations were transferred and analyzed in GraphPad 4.01.

\section{RESULTS}

\section{Analyses of immunological response}

Lymph node cell analyses

Figure 1 shows the percent of the $\mathrm{T}$ helper cells $(\mathrm{CD} 3+\mathrm{CD} 4+)$ in auricular lymph nodes of mice treated with different chemicals and their concentrations, as indicated in Table 1. There were no significant differences between the tested chemicals and the control, nor between the different concentrations used within tested chemical. Figure 2 shows significant changes in percent of CD19+ B cells after treatment with DNCB, TDI, and GA.

Analyses of the density (mean channel fluorescence) of CD44 expression on CD3+CD4 + T cells as an indicator of antigen specific stimulation are presented in Figure 3 as a delta change from cells of control animals. All tested chemicals, except formaldehyde, induced specific response, indicated by the increased expression of CD44 on $\mathrm{T}$ cells. The highest expression of CD44 was observed on lymphocytes from mice treated with the high concentration of TDI, DNCB, TMA, and GA. The increase of CD44 expression after treatment with $\mathrm{ChB}$ was only seen at the medium concentration used for dermal sensitization and intranasal challenge. For FA, none of the applied concentrations induced increased expression of CD44. 


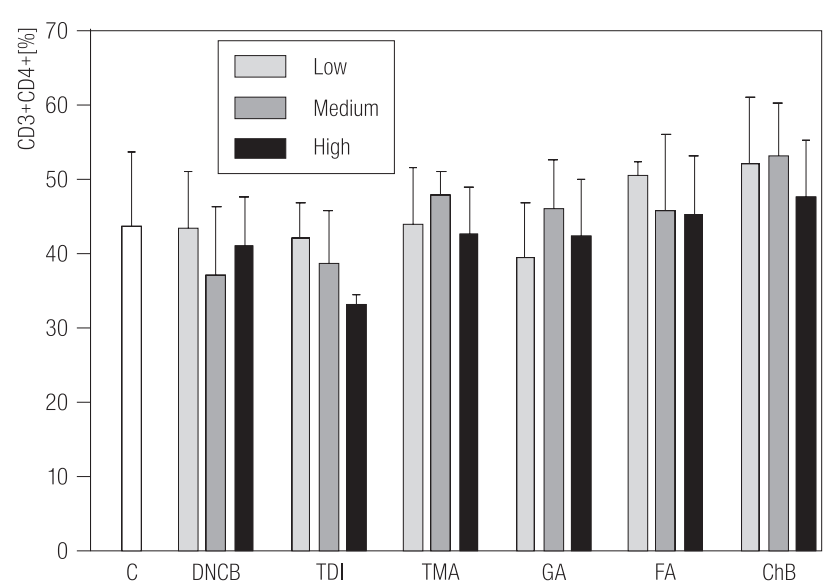

Lymph nodes of 3-5 mice were pooled, and the obtained lymph node cells were stained with anti-CD3 and anti-CD4. Flow cytometry was performed using at least $10^{4}$ cells. $\mathrm{N}$ - number of experiments per concentration per chemicals for the low $(\mathrm{L})$, medium $(\mathrm{M})$ and high $(\mathrm{H})$ concentration used. Results are mean \pm SD. DNCB $(\mathrm{n}=3 \mathrm{~L}, 6 \mathrm{M}, 7 \mathrm{H})$, TDI $(\mathrm{n}=3 \mathrm{~L}, 4 \mathrm{M}, 6 \mathrm{H})$, TMA $(\mathrm{n}=\mathrm{L} 3,4 \mathrm{M}, 6 \mathrm{H})$, $\mathrm{GA}(\mathrm{n}=\mathrm{L} 3,5 \mathrm{M}, 7 \mathrm{H}), \mathrm{FA}(\mathrm{n}=\mathrm{L} 3,3 \mathrm{M}, 3 \mathrm{H}), \mathrm{ChB}(\mathrm{n}=\mathrm{L} 3,3 \mathrm{M}, 3 \mathrm{H})$ and C-control mice $(\mathrm{n}=6)$.

Fig. 1. CD3+CD4+ (T helper cell) subpopulation in auricular lymph nodes of mice.

Table 1. Concentrations of test chemicals used for dermal contact and intranasal challenge

\begin{tabular}{lccc}
\hline \multirow{2}{*}{ Chemicals } & \multicolumn{3}{c}{ Concentration in \% [w/v or v/v] } \\
\cline { 2 - 4 } & $\mathrm{L}$ (Low) & $\mathrm{M}$ (Medium) & $\mathrm{H}($ High $)$ \\
\hline DNCB & $0.2 / 0.2 / 0.02$ & $0.5 / 0.5 / 0.01$ & $1 / 1 / 0.2$ \\
TDI & $0.3 / 0.3 / 0.1^{*}$ & $1 / 1 / 0.3$ & $3 / 3 / 1$ \\
TMA & $0.5 / 0.5 / 0.2$ & $1 / 1 / 0.5$ & $5 / 5 / 1$ \\
GA & $2 / 2 / 0.2$ & $2 / 2 / 0.5$ & $3 / 3 / 1$ \\
FA & $1 / 1 / 0.1$ & $2 / 2 / 0.2$ & $5 / 5 / 0.5$ \\
ChB & $1 / 1 / 0.1$ & $2 / 2 / 0.2$ & $5 / 5 / 0.5$ \\
\hline
\end{tabular}

* The first two symbols identify the concentration of the chemical $(0.3 \%$ TDI) applied dermally on day 1 and 7, and the third symbol identifies the chemical $(0.1 \%$ TDI) instilled intranasally on day 10 .

Based on these analyses, for further experiments we chose the concentrations which caused the highest expression of CD44; except for FA, we chose the high concentration $(5 / 5 / 0,5 \%)$, considering that this induced the highest change in the percent of $\mathrm{CD} 19+\mathrm{B}$ cells.

\section{IL-4 and IFN- $\gamma$ production}

Lymph node cells of animals treated with tested chemicals at the concentrations that induced the highest expression

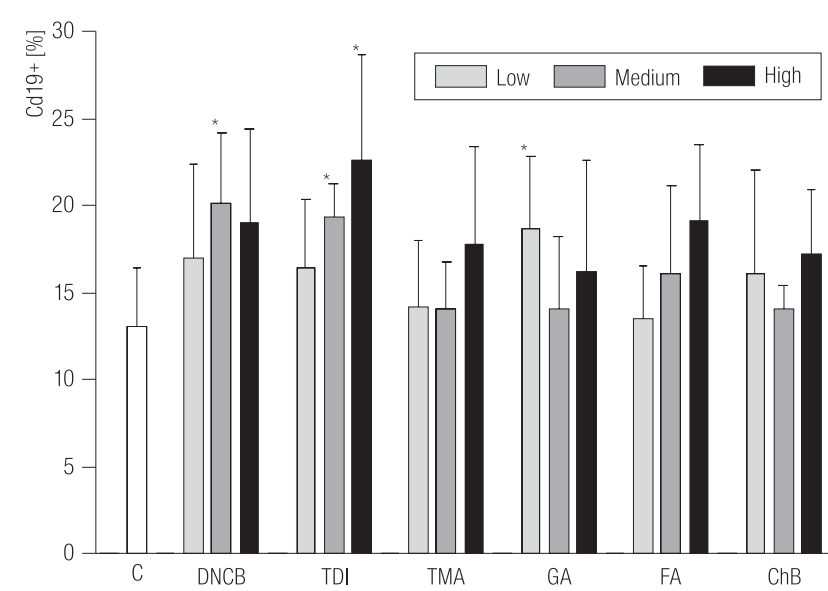

Lymph nodes of 3-5 mice were pooled, and the obtained lymph node cells received a single anti-CD19 staining. Flow cytometry was performed using at least $10^{4}$ cells. $\mathrm{N}$ - number of experiments per concentration per chemicals for the low $(\mathrm{L})$, medium $(\mathrm{M})$ and high $(\mathrm{H})$ concentration used. Results are mean \pm SD. DNCB $(\mathrm{n}=3 \mathrm{~L}, 6 \mathrm{M}, 7 \mathrm{H})$, TDI $(\mathrm{n}=3 \mathrm{~L}, 4 \mathrm{M}, 6 \mathrm{H})$, TMA $(\mathrm{n}=\mathrm{L} 3,4 \mathrm{M}, 6 \mathrm{H})$, $\mathrm{GA}(\mathrm{n}=\mathrm{L} 3,5 \mathrm{M}, 7 \mathrm{H}), \mathrm{FA}(\mathrm{n}=\mathrm{L} 3,3 \mathrm{M}, 3 \mathrm{H}), \mathrm{ChB}(\mathrm{n}=\mathrm{L} 3,3 \mathrm{M}, 3 \mathrm{H})$ and $\mathrm{C}$-control mice $(\mathrm{n}=6)$. *p $<0.05$ by Mann-Whitney test.

Fig. 2. CD19+ (B cell) subpopulation in auricular lymph nodes of mice.

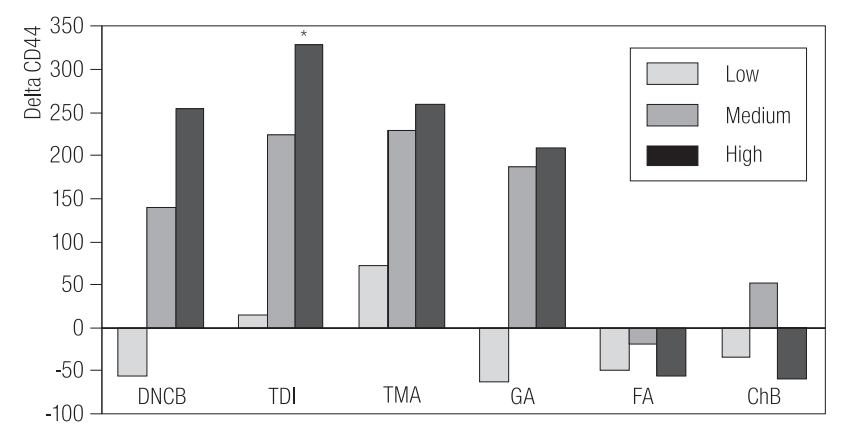

T cells were obtained from pooled lymph node cells after treatment with three different concentrations of test chemicals or vehicle. Data are presented as CD44 MFI delta change of mean values on T cells of treated mice compared with control animals ( $\mathrm{n}=3$ experiments). Statistical analyses were performed by one way ANOVA Bonferroni post test. $* \mathrm{p}<0.05$.

Fig. 3. CD44 density expression (Mean Fluorescence Intensity) on $\mathrm{CD} 3+\mathrm{CD} 4+\mathrm{T}$ cells.

of CD44 on T cells were stimulated in vitro with Con A. Figure 4 shows the levels of IL- 4 and IFN- $\gamma$, measured in undiluted supernatants using ELISA. Both IL-4 and IFN- $\gamma$ levels were increased for all test conditions. Surprisingly, TDI and FA caused a statistically significant increase in IFN- $\gamma$ level compared with the control. Significant 


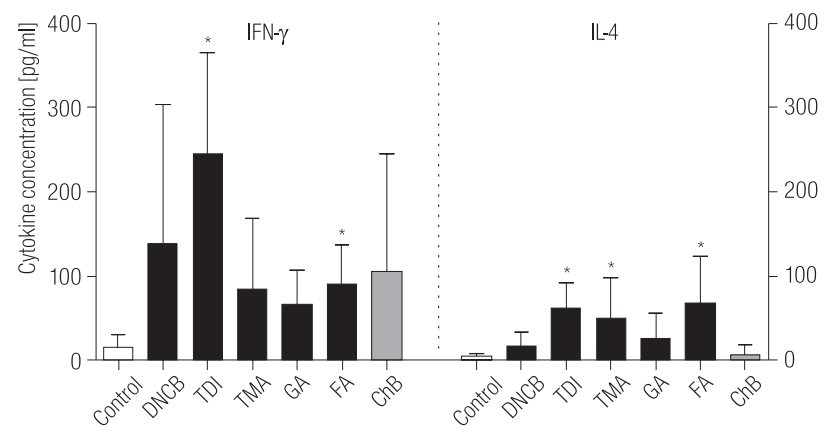

Lymph node cells were obtained from animals treated with tested chemicals at the high concentrations for DNCB, TDI, TMA, GA, FA (black bars), at the medium concentration for $\mathrm{ChB}$ (grey bar) and control mice (white bar). The levels of IFN- $\gamma$ and IL-4 were measured in supernatants after stimulation with concanavalin $\mathrm{A}$.

Results are mean $\pm \mathrm{SD}, \mathrm{n}=3$ experiments, each consisting of 3 mice. ${ }^{*} \mathrm{p}<0.05$ by Mann-Whitney test.

Fig. 4. IFN- $\gamma$ and IL-4 in vitro production by auricular lymph node cells.

differences from the control for IL-4 concentration were reached in lymphocytes from TDI-, TMA- and FA-treated mice, and the levels of this cytokine for all chemicals tested were much lower than those of IFN- $\gamma$.

\section{IL-4 and IFN- $\gamma$ mRNA expression}

Figure 5 shows the expression of mRNA for IL-4 and IFN- $\gamma$, estimated by Real-Time PCR. Analyses of mRNA expression show that DNCB and GA induced the highest expression of IFN- $\gamma$ and much higher than of IL-4. In con-

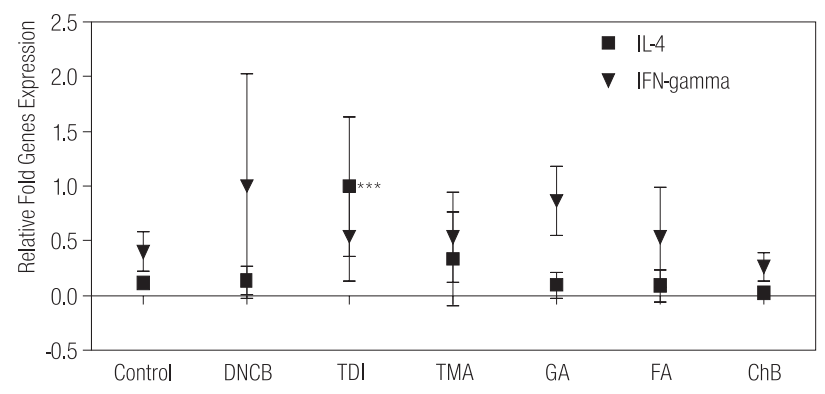

IL-4 and IFN- $\gamma$ mRNA expression was assessed in RNA isolated from whole lymph nodes by Real-Time PCR. Data is presented as Relative Quantity \pm SD (Relative to zero) of three cDNA strains obtained from three independent syntheses from RNA samples, which were isolated from three mice in each group of animals (treatment or control). Statistical analyses were performed by one way ANOVA Bonferroni post test; Control vs. TDI. $* * * p<0.001$.

Fig. 5. IL-4 and IFN- $\gamma$ gene expression in auricular lymph nodes.

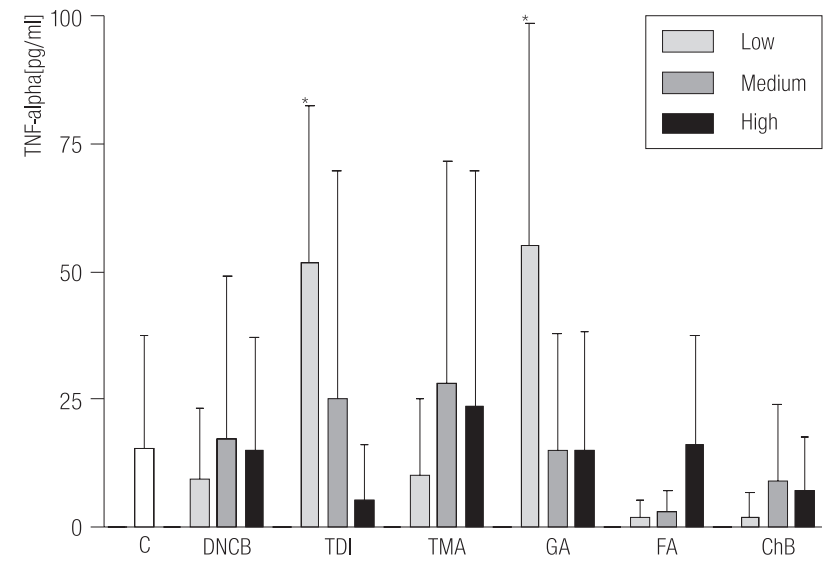

TNF-alpha levels were assessed in BAL of control mice $(\mathrm{n}=12)$ and mice exposed to 3 different concentrations ( $\mathrm{L}-$ low, $\mathrm{M}-$ medium, $\mathrm{H}$ - high) of DNCB ( $\mathrm{n}=\mathrm{L10}$, M9, H8), TDI ( $\mathrm{n}=\mathrm{L10}$, M9, H9), TMA (n = L9, M8, H9), GA (n = 12, M8, H9), FA (n = 9) and ChB $(\mathrm{n}=9)$. Statistical analyses were performed by Mann-Whitney test. * $\mathrm{p}<0.05, \mathrm{n}-$ number of animals per group.

Fig. 6. TNF-alpha level in BAL.

trast, only TDI, but not TMA, showed advantage of IL-4 mRNA expression in comparison to IFN- $\gamma$.

\section{Lung inflammatory reactions}

Microscopical analyses of cells obtained from BAL did not show significant infiltrates of inflammatory cells (neutrophils or lymphocytes) and their content did not exceed $4 \%$ of all cells. In most studied samples, 98\% consisted of macrophages (data not shown).

Analyzes of soluble factors indicative of inflammatory response in BAL fluid included TNF-alpha and MIP-2. MIP-2 chemokine was not detected by ELISA in BAL fluid, whereas TNF-alpha was found at significantly higher level in comparison to control animals after exposure of mice to TDI and GA at the lowest applied exposure concentrations (Figure 6).

\section{DISCUSSION}

In the occupational setting, the number of new chemicals with the potential to cause allergies increases. The lack of knowledge about pro-allergic potentials of these new chemicals, in combination with insufficiently recognized potentials of these that are already commercially available substantiates the need for the development of murine model for assessment of the potentials of chemicals 
to induce allergies. Until now, there are a few validated methods to identify chemical capable of causing contact allergy, e.g. the guinea pig maximization test [31], the Buehler test [32] and the recently validated local lymph node assay [33]. Nevertheless, no validated method is yet available for testing the potentials of chemicals to cause respiratory sensitization. In our present study we attempt to provide further information that could help establish the model for assessment of the potentials of chemicals to induce respiratory sensitization. The selected chemicals that could help us establish this model included those that are known respiratory sensitizers (TDI, TMA), known skin sensitizer (DNCB) and those with uncertain sensitising activity (GA, FA, ChB). The protocol applied by ourselves and the analyzed parameters for chosen chemicals could provide information that, when compared between the chemicals, could help us to determine the correctness of the selected model. We based our animal model and exposure protocol on previously published data that showed early and late ventilatory changes after 2 dermal skin exposures and one intranasal challenge with TDI [12] which coincided with lung inflammation. Furthermore, these observations were confirmed also for another asthmogen, TMA, but not DNCB [13] and were due to antigen-specific immunological responses [14]. Following similar protocol, first we sought to determine the ability of chemicals to be irritants or specific immune stimulants based on the marker of T cell activation, CD44, described earlier by other authors [24,25].

The development of $\mathrm{T}$ cells from naive to memory/activated cells includes changes in migratory properties and thus differences in expression of some adhesion molecules that enable these cells to enter the tissues. One of the markers of naive or activated T cells are CD62L (L-selectin) and CD44, respectively. L-selectin enables naive $\mathrm{T}$ cells to circulate between blood and lymph nodes by binding to the ligands found on high endothelial venules of these lymphoid organs. Once T cells encounter specific antigen, their phenotype changes in the way to enable these cells to enter into the peripheral tissues where the inflammatory reaction takes place. These changes are accompanied by increased expression of adhesion molecules, such as
CD44. Antigen-specific stimulation but not irritation has been previously shown to change the phenotype of $\mathrm{T}$ cells in the way that the high expression of CD62L on naive $\mathrm{T}$ cells has been decreased on memory/activated $\mathrm{T}$ cells that instead show high expression of CD44 [25]. Furthermore, the requirements of CD44 molecule for skin allergic reactions were further confirmed in the studies where CD44 knock-out mice had significantly reduced infiltrates of $\mathrm{T}$ cells in the skin site, following the challenge with allergen. Additionally, this study has proved that such reaction and dependence on CD44 expression by T cells can happen for allergen causing immediate, IgE dependent, allergic reaction [24]. Based on this knowledge, we used the expression of CD44 for monitoring the antigen-activated $\mathrm{T}$ cells in our model of chemical-induced asthma. Formaldehyde was the only chemical that did not yield an increased expression of CD44 on the T cells. For TDI, TMA and DNCB a dose-dependent increase of the CD44 expression on the T-cells was noted.

Based on the data of CD44 expression, we decided to select a single test concentration of each chemical to be used in our subsequent experiments.

Respiratory sensitization is seen as a consequence of immune responses to antigen with preferential production of Th2 cytokines, IL-4, IL-13, IL-5 but not IFN- $\gamma$ [34-37]. T-helper cell 2 cytokines, IL-4, IL-13 and IL-5 direct humoral responses and lead to increased expression of $\operatorname{IgE}$ [38], maturation and growth of eosinophils [39]. These are important elements in development of asthma. On the other hand, IFN- $\gamma$ is a major cytokine of a Th1 profile and participates in cell-dependent mechanisms of immune response of skin contact allergy [40]. The difference between these two types of immune responses in regard of cytokine production is rather quantitative and not absolute. Since it has been suggested frequently that respiratory sensitizers cause Th2 type responses, while dermal sensitizers produce Th1 type response, the estimation of the levels of cytokines, mainly IL-4 and IFN- $\gamma$, is considered to be an indication of chemical's potential to cause sensitization. This approach has been used for several years and studied in different animal models, using different chemical compounds and different techniques [8,26-29,41]. 
However, most of them, while focused on immunological observations, lacked analyses of ventilatory responses. Using ELISA or mRNA expression techniques it has already been shown that cytokine production from cells of lymph nodes draining the site of chemical application for some chemicals shows specific profiles of synthesis that characterize processes of dermal or respiratory sensitization $[8,27,28]$. In our model, based on ELISA technique, we failed to show a specific profile of the cytokine production and found that both IL-4 as well as IFN- $\gamma$ were increased after in vitro lymph node cell stimulation [42]. These analyses were confirmed in our present study and reported by other authors previously [17]. Nevertheless, we additionally implemented the analyses of mRNA expression for IL-4 and IFN- $\gamma$ using Real-Time PCR in this study. Due to the fact that mRNA is much easier to detect than protein, we performed Real-Time PCR using total RNA isolated from whole lymph nodes. Using this technique we have found specific mRNA cytokine profile expression after treatment with the different chemicals. TDI and TMA clearly induced the highest IL-4 mRNA levels, whereas DNCB produced the highest levels of IFN- $\gamma$ mRNA. Expression of both acids for the rest of chemicals was lower, with the exception of glutaraldehyde that showed enhanced expression of mRNA for IFN- $\gamma$ but not for IL-4, indicating the dermal sensitization properties of this product, as already shown by some authors [18]. Increased expression of mRNA for IL-4 or IFN- $\gamma$ corresponds to the potential of TDI, TMA, DNCB and glutaraldehyde to induce CD44 expression. However, the effect of these immunological changes were not evident from our investigations of inflammatory changes in lungs. For each applied concentration of chemicals we have not found significant infiltrates of inflammatory cells nor neutrophil chemoatractant MIP-2 in BAL. It is only the levels of TNF-alpha after exposure to low TDI and GA concentrations that were found significantly elevated vs. control, but the meaning of those changes is difficult to explain, the more so that higher exposures did not produce such changes.

The technique of Real-Time PCR allows us to analyze the immune responses as seen by IL-4 and IFN- $\gamma$ mRNA expression in ex vivo conditions, without the need for in vitro cell stimulation as it is in case of analyses of supernatant levels of cytokines. The drawback of in vitro stimulation using a mitogen is that this stimulus activates cells regardless of antigen specificity and greatly enhances the production of different cytokines of all isolated cells, making it less possible to detect the production of these proteins from cells that developed in response to exposure to a test chemical. Isolation of RNA from whole lymph nodes without mitogen cell stimulation provides better picture of the effect of chemical exposure and provides the information about the pattern of immune response. However, our data did not confirm the asthma-inducing potential of FA and GA noted in human studies [15,43]. A possible reason for this might be that these compounds do not induce this condition through classical, antigen-specific immune responses but rather through the effect of irritant-induced responses. This kind of response has already been shown before, e.g. for benzalkonium chloride that is capable of inducing skin-contact allergy, while it should not be classified as a skin sensitizer, but rather as a skin irritant $[44,45]$. Our data further confirms these findings. Further validation of this hypothesis requires performing experiments to see if it is possible to find ventilatory changes induced by FA, GA, and ChB.

This model still needs further investigations, which would include extension of the list of cytokines for which RealTime PCR would be performed and other chemicals. Together with previously published data $[13,14]$ our model should include also ventilatory measurements that are complementary with immunological parameters in the way to indicate the chemical potentials of respiratory sensitization.

\section{REFERENCES}

1. Janeway CA, Jason J, Jason JM. How T lymphocytes recognize antigen. Crit Rev Immunol 1980;1(2):133-64.

2. Depta JP, Altznauer F, Gamerdinger K, Burkhart C, Weltzien HU, Pichler WJ. Drug interaction with T-cell receptors: T-cell receptor density determines degree of cross-reactivity. J Allergy Clin Immunol 2004;113(3):519-27. 
3. Haneke KE, Tice RR, Carson BL, Margolin BH, Stokes WS. ICCVAM evaluation of the murine local lymph node assay. Data analyses completed by the National Toxicology Program Interagency Center for the Evaluation of Alternative Toxicological Methods. Regul Toxicol Pharmacol 2001;34:274-86.

4. Cockshott A, Evans P, Ryan CA, Gerberick GF, Betts CJ, Dearman RJ, et al. The local lymph node assay in practice: a current regulatory perspective. Hum Exp Toxicol 2006;25: 387-94.

5. Ehling G, Hecht M, Heusener A, Huesler J, Gamer AO, van Loveren H, et al. An European inter-laboratory validation of alternative endpoints of the murine local lymph node assay: first round. Toxicology 2005;212:60-8.

6. Ehling G, Hecht M, Heusener A, Huesler J, Gamer AO, van Loveren $\mathrm{H}$, et al. An European inter-laboratory validation of alternative endpoints of the murine local lymph node assay: 2 nd round. Toxicology 2005;212:69-79.

7. Dearman RJ, Moussavi A, Kemeny DM, Kimber I. Contribution of CD4+ and CD8+ T lymphocyte subsets to the cytokine secretion patterns induced in mice during sensitization to contact and respiratory chemical allergens. Immunology 1996;89: $502-10$.

8. Dearman RJ, Kimber I. Cytokine profiling and chemical allergy. Toxicol Appl Pharmacol 2002;85:228-29.

9. Dearman RJ, Skinner RA, Humphreys NE, Kimber I. Methods for the identification of chemical respiratory allergens in rodents: comparisons of cytokine profiling with induced changes in serum IgE. J Appl Toxicol 2003;23:199-207.

10. Warbrick EV, Dearman RJ, Kimber I. Induced changes in total serum IgE concentration in the Brown Norway rat: potential for identification of chemical respiratory allergens. J Appl Toxicol 2002;22:1-11.

11. Warbrick EV, Dearman RJ, Kimber I. IgG and IgE antibody responses following exposure of Brown Norway rats to trimellitic anhydride: comparison of inhalation and topical exposure. Toxicology 2002;172:157-68.

12. Vanoirbeek JAJ, Mandervelt C, Cunningham AR, Hoet PHM, Xu H, Vanhooren HM, et al. Validity of methods to predict the respiratory sensitizing potential of chemicals: A study with a piperidinyl chlorotriazine derivative that caused an outbreak of occupational asthma. Toxicol Sci 2003;76:338-46.
13. Vanoirbeek JA, Tarkowski M, Ceuppens JL, Verbeken EK, Nemery B, Hoet PH. Respiratory response to toluene diisocyanate depends on prior frequency and concentration of dermal sensitization in mice. Toxicol Sci 2004:80:310-21.

14. Vanoirbeek JA, Tarkowski M, Vanhooren HM, de Vooght V, Nemery B, Hoet PH. Validation of a mouse model of chemical-induced asthma using trimellitic anhydride, a respiratory sensitizer, and dinitrochlorobenzene, a dermal sensitizer. J Allergy Clin Immunol 2006;117:1090-7.

15. Di Stefano F, Siriruttanapruk S, McCoach JS, Burge PS. Occupational asthma due to glutaraldehyde. Monaldi Arch Chest Dis 1998;53:50-5.

16. Shaffer MP, Belsito DV. Allergic contact dermatitis from glutaraldehyde in health-care workers. Contact Dermatitis 2000;43:150-6.

17. Ulrich P, Grenet O, Bluemel J, Vohr HW, Wiemann C, Grundler O, et al. Cytokine expression profiles during murine contact allergy: Thelper 2 cytokines are expressed irrespective of the type of contact allergen. Arch Toxicol 2001;75:470-9.

18. Azadi S, Klink KJ, Meade BJ. Divergent immunological responses following glutaraldehyde exposure. Toxicol Appl Pharmacol 2004;197:1-8.

19. Bardana EJ, Montanaro A. Formaldehyde: an analysis of its respiratory, cutaneous, and immunologic effects. Ann Allergy 1991;66:441-52.

20. Bardana EJ, Andrach RH. Occupational asthma secondary to low molecular weight agents used in the plastic and resin industries. Eur J Respir Dis 1983;64:241-51.

21. Nettis E, Colanardi MC, Soccio AL, Ferrannini A, Tursi A. Occupational irritant and allergic contact dermatitis among healthcare workers. Contact Dermatitis 2002;46:101-7.

22. Bernstein JA, Stauder T, Bernstein DI, Bernstein IL. A combined respiratory and cutaneous hypersensitivity syndrome induced by work exposure to quaternary amines. J Allergy Clin Immunol 1994;94:257-9.

23. Sikorski EE, Gerberick GF, Ryan CA, Miller CM, Ridder GM. Phenotypic analysis of lymphocyte subpopulations in lymph nodes draining the ear following exposure to contact allergens and irritants. Fundam Appl Toxicol 1996;34:25-35.

24. Gonda A, Gal I, Szanto S, Sarraj B, Glant Tt, Hunyadi J, et al. CD44, but not L-selectin, is critically involved 
in leucocyte migration into the skin in a murine model of allergic dermatitis. Exp Dermatol 2005;14:700-8.

25. Gerberick GF, Cruse LW, Miller CM, Sikorski EE, Ridder GM. Selective modulation of $T$ cell memory markers CD62L and CD44 on murine draining lymph node cells following allergen and irritant treatment. Toxicol Appl Pharmacol 1997;146:1-10.

26. Dearman RJ, Betts CJ, Humphreys N, Flanagan BF, Gilmour NJ, Basketter DA, et al. Chemical allergy: considerations for the practical application of cytokine profiling. Toxicol Sci 2003;71:137-45.

27. Dearman RJ, Kimber I. Cytokine fingerprinting: characterization of chemical allergens. Methods 1999;19:56-63.

28. Dearman RJ, Kimber I. Cytokine fingerprinting and hazard assessment of chemical respiratory allergy. J Appl Toxicol 2001;21:153-63.

29. Dearman RJ, Filby A, Humphreys IR, Kimber I. Interleukins 5 and 13 characterize immune responses to respiratory sensitizing acid anhydrides. J Appl Toxicol 2002;22:317-25.

30. Tarlo SM. Occupational asthma: a valid model for adult asthma? Curr Opin Allergy Clin Immunol 2003;3:91-4.

31. Magnusson B, Kligman AM., The identification of contact allergens by animal assay. The guinea pig maximization test. J Invest Dermatol 1969;52: 268-76.

32. Buehler EV. Occlusive patch method for skin sensitization in guinea pigs: the Buehler method. Food Chem Toxicol 1994;32:97-101.

33. Gerberick GF, Ryan CA, Dearman RJ, Kimber I. Local lymph node assay (LLNA) for detection of sensitization capacity of chemicals. Methods 2007;41(1):54-60.

34. Robinson DS, Ying S, Bentley AM, Meng Q, North J, Durham SR, et al. Relationships among numbers of bronchoalveolar lavage cells expressing messenger ribonucleic acid for cytokines, asthma symptoms, and airway methacholine responsiveness in atopic asthma. J Allergy Clin Immunol 1993;92:397-403.

35. Robinson DS, Hamid Q, Jacobson M, Ying S, Kay AB, Durham SR. Evidence for Th2-type Thelper cell control of allergic disease in vivo. Springer Semin Immunopathol 1993;15:17-27.

36. Robinson D, Hamid Q, Bentley A, Ying S, Kay AB, Durham SR. Activation of CD4+ T cells, increased TH2-type cytokine $m R N A$ expression, and eosinophil recruitment in bronchoalveolar lavage after allergen inhalation challenge in patients with atopic asthma. J Allergy Clin Immunol 1993;92:313-24.

37. Ohkawara Y, Lei XF, Stämpfli MR, Marshall JS, Xing Z, Jordana M. Cytokine and eosinophil responses in the lung, peripheral blood, and bone marrow compartments in a murine model of allergen-induced airways inflammation. Am J Respir Cell Mol Biol 1997;16:510-20.

38. Finkelman FD, Holmes J, Katona IM, Urban JF Jr, Beckmann MP, Park LS, et al. Lymphokine control of in vivo immunoglobulin isotype selection. Annu Rev Immunol 1990;8:303-33.

39. Wardlaw AJ. Eosinophils in the 1990s: new perspectives on their role in health and disease. Postgrad Med J 1994; 70:536-52.

40. Morton CA, Campbell I,. MacKie RM. Gamma-interferon in evolving allergic contact dermatitis reactions. Br J Dermatol 1996;135:853-5.

41. Kimber I, Gerberick GF, van Loveren H, House RV. Chemical allergy: molecular mechanisms and practical applications. Fundam Appl Toxicol 1992;19:479-83.

42. Tarkowski M, Vanoirbeek JAJ, Vanhooren HM, de Vooght V, Mercier CM, Ceuppens J, et al. Immunological determinants of ventilatory changes induced in mice by dermal sensitization and respiratory challenge with toluene diisocyanate. Am J Physiol Lung Cell Mol Physiol 2007;36:L207-14.

43. Kim CW, Song JS, Ahn YS, Park SH, Park JW, Noh JH, et al. Occupational asthma due to formaldehyde. Yonsei Med J 2001;42:440-5.

44. Basketter DA, Marriott M, Gilmour NJ, White IR. Strong irritants masquerading as skin allergens: the case of benzalkonium chloride. Contact Dermatitis 2004;50:213-7.

45. Oiso N, Fukai K, Ishii M. Irritant contact dermatitis from benzalkonium chloride in shampoo. Contact Dermatitis 2005; 52:54. 